\title{
Pengaruh Mobilisasi Ibu Post Partum terhadap Pengeluaran Kolostrum
}

Fitriyanti ${ }^{1}$, Joserizal Serudji ${ }^{2}$, Sunesni ${ }^{3}$

\begin{abstract}
Abstrak
Sasaran Making Pregnancy Safer (MPS) menurunkan Angka Kematian Bayi (AKB) hingga 28 per 1000 kelahiran hidup dengan salah satu upaya yang dapat dilakukan melalui pemberian kolostrum. Tujuan penelitian ini adalah untuk mengetahui pengaruh mobilisasi ibu post partum terhadap pengeluaran kolostrum. Penelitian ini merupakan quasi eksperimen dengan post test only group design. Data dianalisis menggunakan uji Chi-Square dan Fisher's Exact Test. Hasil analisis data menunjukkan persentase pengeluaran kolostrum early pada kelompok intervensi $72,2 \%$ dan kelompok kontrol 50,0\%. Persentase pengeluaran kolostrum late pada kelompok intervensi $27,8 \%$ dan kelompok kontrol 50,0\%. Tidak terdapat pengaruh bermakna mobilisasi ibu post partum terhadap pengeluaran kolostrum dengan nilai $p$ value $0,305(>0,05)$. Tidak terdapat pengaruh bermakna tingkat stres dan IMT ibu terhadap pengeluaran kolostrum dengan nilai $p$ value $1,000(>0,05)$. Terdapat pengaruh bermakna daya hisap bayi terhadap pengeluaran kolostrum dengan nilai $p$ value $0,047 \quad(<0,05)$.Dari hasil penelitian disimpulkan persentase pengeluaran kolostrum early kelompok intervensi lebih besar dibandingkan kelompok kontrol, namun secara statistik tidak terdapat pengaruh bermakna mobilisasi ibu post partum terhadap pengeluaran kolostrum pada kedua kelompok tersebut. Tidak terdapat pengaruh bermakna tingkat stres dan IMT ibu terhadap pengeluaran kolostrum, terdapat pengaruh bermakna daya hisap bayi terhadap pengeluaran kolostrum.
\end{abstract}

Kata kunci: post partum, mobilisasi, kolostrum,

\begin{abstract}
Target of Making Pregnancy Safer (MPS) to improve Infant Mortality Rate (IMR) to 28 per 1000 live births. One of effort to do is giving colostrum. The objective of this study was to determine the effect of maternal postpartum mobilization against eject of colostrum. This study was a quasi experiment with post-test only group design. Data were analyzed using Chi-square and Fisher's Exact test. Result of this study showed that early colostrums in the intervention group was $72.2 \%$ while in control group only $50 \%$. Late colostrums in intervention group was $27.8 \%$ compared $50 \%$ in the control group. There was no significant effect between maternal postpartum mobilization against eject of colostrum with $p$ value 0.305 (> 0.05). No significant effect on stress level and Body Mass Index (BMI) and eject of colostrum with $p$ value was $1.000(>0.05)$ but significant effect occurred between infant suction power against colostrums spending with $p$ value was $0.047(<0.05)$. It can be concluded that percentage of early eject of colostrum was greater in intervention group than in control group, but statistically there was no significant effect among maternal postpartum mobilization, stress level and BMI against colostrums spending in both group. Significant effect only showed between infant suction power against colostrums spending.
\end{abstract}

Keywords: postpartum, mobilization, colostrums

Affiliasi Penulis :1. Program Studi Magister Kebidanan FK UNAND (Fakultas Kedokteran Universitas Andalas Padang), 2. Bagian Kebidanan FK UNAND/RSUP Dr. M. Djamil Padang, 3. STIKes MERCUBAKTI Jaya Padang

Korespondensi: Fitriyanti, E-mail: fitriyantiasrun@yahoo.co.id, Telp: 085264554472

\section{PENDAHULUAN}

Tolok ukur dan indikator suatu negara dalam menentukan tingkat kesehatan masyarakat salah satunya adalah Angka Kematian Bayi (AKB). Di 
Indonesia pada tahun 2012, menurut SDKI (Survei Demografi dan Kesehatan Indonesia) tercatat AKB masih sangat tinggi yaitu 32 kematian per 1000 kelahiran hidup, itu artinya dalam satu tahun sekitar 125.000 bayi meninggal sebelum mencapai usia satu tahun dan Angka Kematian Neonatal (AKN) kisaran 20 per 1.000 kelahiran hidup. Target MPS (Making Pregnancy Safer) yaitu strategi untuk meningkatkan kesehatan ibu dan bayi baru lahir pada tahun 2010 menurunkan AKN menjadi 16 per 1000 kelahiran hidup dan menurunkan AKB menjadi kurang dari 32 per 1000 kelahiran hidup pada tahun 2015, yang diikuti dengan adanya target review status MDGs (Millenium Development Goals) target MDGs tahun 2015 terhadap penurunan AKB menjadi 28 per 1000 kelahiran hidup. $^{1}$

Target MDGs agar tercapai maka perlu beberapa upaya konkrit dan tindakan yang efektif demi meningkatkan kualitas bayi melalui pemberian ASI yang tepat terutama ASI kolostrum yang keluar pada hari pertama sampai hari ketiga. Kolostrum mengandung zat gizi berkualitas tinggi berupa protein dan antibody yang siap melindungi bayi ketika kondisi bayi masih sangat lemah, serta juga berguna untuk pertumbuhan dan perkembangan kecerdasan bayi. ${ }^{2}$

ASI bermanfaat untuk menjaga ketahanan tubuh bayi karena mengandung zat anti infeksi sebagaimana Carina Venter dan Tara Dean menyatakan bahwa ASI mengandung za immunomodulator serta zat gizi yang unik. Selain itu, ASI mengandung zat gizi lengkap seperti karbohidrat berupa laktosa, lemak yang banyak (asam lemak tak jenuh ganda), protein utama berupa lactabumin yang mudah dicerna, kandungan vitamin dan mineral yang banyak. $^{3}$

Disamping involusi, terjadi juga perubahanperubahan penting yakni laktasi dan gangguan laktasi yang merupakan salah satu penyebab penurunan fundus uteri terganggu. Apabila proses involusi ini tidak berjalan dengan baik maka akan timbul suatu keadaan yang disebut subinvolusi uteri yaitu tidak mengecilnya kembali rahim kebentuk semula seperti sebelum hamil. Hal ini akan menyebabkan terjadinya perdarahan dalam masa 40 hari, yang bisa disebabkan karena ibu tidak mau menyusui, takut untuk mobilisasi atau melakukan pergerakan pada dua jam setelah persalinan atau aktifitas yang kurang. ${ }^{4} \mathrm{Hal}$ ini didukung oleh Larsen bahwa perlunya latihan olah tubuh pada ibu post partum untuk produksi ASI. ${ }^{5} \mathrm{Hal}$ senada juga dikemukakan oleh Dewey bahwa latihan gerak tubuh ibu setelah persalinan tidak berefek negatif bagi bayi dan menyusui. ${ }^{6}$

Menyusui yang paling mudah dan sukses dilakukan adalah bila si ibu sendiri sudah siap fisik dan mentalnya untuk melahirkan dan menyusui namun hal ini tidak semudah yang dibayangkan. Fenomena yang masih sering terlihat dimasyarakat ialah masih merasa lelah setelah menjalani proses persalinan sehingga ibu menjadi takut untuk bergerak atau melakukan mobilisasi, padahal dengan ibu melakukan mobilisasi akan dapat melancarkan peredaran darah ibu sehingga mempercepat pengeluaran ASI. Sebagaimana pendapat West dalam Hell, 2009 bahwa kelelahan merupakan salah satu faktor yang menyebabkan ibu tidak menyusui. ${ }^{7}$

Penelitian bertujuan mengetahui pengaruh mobilisasi ibu post partum terhadap pengeluaran kolostrum.

\section{METODE}

Penelitian ini merupakan penelitian kuantitatif dengan rancangan quasi experiment dengan post test only control group design untuk mengetahui pengaruh mobilisasi ibu terhadap pengeluaran kolostrum di RSU Bahteramas Sulawesi Tenggara.

Tempat penelitian adalah di ruang nifas RSU Bahteramas Sulawesi Tenggara. Waktu penelitian dilakukan selama enam bulan. Populasi penelitian ini adalah semua ibu post partum normal di RSU Bahteramas Sulawesi Tenggara. Subjek penelitian yang dipilih adalah semua populasi yang memenuhi kriteria inklusi dan eksklusi. Kriteria inklusi dalam penelitian ini adalah bersedia menjadi responden, ibu post partum normal yang kolostrumnya belum keluar, lbu melahirkan bayi hidup, sedangkan kriteria ekslusi adalah lbu post partum normal yang kolostrumnya 
sudah keluar, Ibu nifas dengan puting susu yang inverted dan lbu nifas dengan bayi kelainan kongenital/bayi meninggal.

Kelompok kontrol adalah ibu yang memenuhi kriteria inklusi tetapi menolak untuk melakukan mobilisasi, ibu dengan masalah atau komplikasi pada kala tiga dan masa nifas sehingga tidak dapat melakukan mobilisasi dini. Prosedur pengambilan sampel menggunakan Random Block, dimana semua subjek yang datang dan memenuhi kriteria inklusi dikelompokkan dalam 2 kelompok dan diurut berdasarkan tabel random block dengan perhitungan jumlah sampel berdasarkan data kategorik, maka diperoleh:

$$
\begin{aligned}
n & =\text { za.p.q } \\
d^{2} & \\
& =\frac{1,65^{2} \cdot 0,06 \cdot 0,94}{0,01} \\
& =16
\end{aligned}
$$

Ket :

$\mathrm{n}$ =besar sampel

$\mathrm{z}_{\alpha}=$ tingkat kemaknaan $(\alpha=10 \%=1,65)$

$\mathrm{p}=$ proporsi keadaan yang ditetapkan dari pustaka $(0,06)$

$q$ =nilai dari $1-p$

$\mathrm{d}=$ tingkat ketepatan absolut yang dikehendaki $(0,10)$

Untuk menghindari Drop Out subjek ditambah $10 \%$ sehingga menjadi 18 . Subyek diberi informasi mengenai gerakan mobilisasi, daya hisap bayi, status gizi ibu menyusui, pengertian kolostrum, keadaan psikologis ibu yang menggambarkan tingkat stress ibu, gambaran klinis pengeluaran kolostrum dan cara mengetahui pengeluaran kolostrum. Ceklist penilaian gerakan mobilisasi dinilai setiap $1 \mathrm{x}$ dalam sehari yaitu pada pada hari pertama dilakukan pada 2-6 jam post partum sedangkan hari kedua dan ketiga setiap jam 7.00 pagi. Untuk penilaian daya hisap bayi, dan pengeluaran kolostrum dinilai setiap $3 \times$ sehari yaitu pada jam 7 pagi setelah sarapan pagi, jam 12.00 siang setelah makan siang dan jam 19.00 malam setelah makan malam.

Status gizi (IMT/Indeks Massa Tubuh) ibu dinilai dengan melakukan pengukuran timbangan berat badan ibu menggunakan timbangan injak digital (Seca) dengan ketelitian $0,1 \mathrm{~kg}$, tinggi badan menggunakan microtoise dengan ketelitian $0,1 \mathrm{~cm}$.
Sedangkan tingkat stress ibu diukur dengan menggunakan kuisioner skala DAS (Depression Anxiety Stress Scale) 42.

Setelah data diperoleh kemudian diolah dan disajikan dalam bentuk tabel dan untuk mengetahui pengaruh mobilisasi dan faktor lain (IMT, tingkat stres dan daya hisap bayi) terhadap pengeluaran kolostrum pada kedua kelompok dilakukan uji chi square dan Fisher Exact Test dengan nilai $\alpha=0,05$ diambil sebagai batas kemaknaan. ${ }^{8}$

\section{HASIL}

Responden pada penelitian ini terdiri dari ibu nifas yang dilakukan mobilisasi sebagai kelompok intervensi dan ibu nifas yang tidak dilakukan mobilisasi sebagai kelompok kontrol.

Dari 36 responden ibu nifas, dibagi dalam dua kelompok yaitu kelompok intervensi berjumlah 18 orang dan kelompok kontrol berjumlah 18 orang.

Tabel 1. Distribusi Responden Kelompok Mobilisasi

\begin{tabular}{lcc}
\hline $\begin{array}{l}\text { Kelompok } \\
\text { Mobilisasi }\end{array}$ & Frekuensi & $\%$ \\
\hline Intervensi & 18 & 50 \\
Kontrol & 18 & 50 \\
\hline Total & $\mathbf{3 6}$ & $\mathbf{1 0 0}$
\end{tabular}

Tabel 1 menunjukkan bahwa dari 36 responden, terdapat masing-masing 18 responden untuk kelompok intervensi (mobilisasi) dan kelompok kontrol (tidak mobilisasi).

Tabel 2. Distribusi Frekuensi Status IMT Responden

\begin{tabular}{lcccc}
\hline & \multicolumn{4}{c}{ Kelompok } \\
\cline { 2 - 5 } Status & \multicolumn{2}{c}{ Intervensi } & \multicolumn{2}{c}{ Kontrol } \\
\cline { 2 - 5 } IMT & $\mathbf{f}$ & $\%$ & $\mathbf{f}$ & $\%$ \\
\hline Kurang & 2 & 11,1 & 3 & 16,7 \\
Normal & 14 & 77,8 & 13 & 72,2 \\
Lebih & 2 & 11,1 & 2 & 11,1 \\
\hline Total & $\mathbf{1 8}$ & $\mathbf{1 0 0}$ & $\mathbf{1 8}$ & $\mathbf{1 0 0}$ \\
\hline
\end{tabular}

Tabel 2 menunjukkan bahwa untuk kelompok intervensi responden sebagian besar berada pada status IMT normal yaitu sebanyak 14 orang $(77,8 \%)$, sedangkan untuk kelompok kontrol sebagian besar responden juga berada pada status IMT normal yaitu 13 orang $(72,2 \%)$ 
Tabel 3. Distribusi Frekuensi Tingkat Stres Ibu Responden

\begin{tabular}{lcccc}
\hline \multirow{2}{*}{ Tingkat } & \multicolumn{4}{c}{ Kelompok } \\
\cline { 2 - 5 } Stres & \multicolumn{2}{c}{ Intervensi } & \multicolumn{2}{c}{ Kontrol } \\
\cline { 2 - 5 } & $\mathbf{f}$ & $\%$ & $\mathbf{f}$ & $\%$ \\
\hline Normal & 5 & 27,8 & 4 & 22,2 \\
Ringan & 11 & 61,1 & 12 & 66,7 \\
Berat & 2 & 11,1 & 2 & 11,1 \\
\hline Total & $\mathbf{1 8}$ & $\mathbf{1 0 0}$ & $\mathbf{1 8}$ & $\mathbf{1 0 0}$ \\
\hline
\end{tabular}

Tabel 3 menunjukkan bahwa untuk kelompok intervensi sebagian besar responden mengalami tingkat stres ringan yaitu 11 orang $(61,1 \%)$, sedangkan untuk kelompok kontrol sebagian besar responden juga mengalami tingkat stres ringan yaitu 12 orang $(66,7 \%)$.

Tabel 4. Distribusi Frekuensi Daya Hisap Bayi Responden

\begin{tabular}{lcccc}
\hline & \multicolumn{5}{c}{ Kelompok } \\
\cline { 2 - 5 } Daya & \multicolumn{2}{c}{ Intervensi } & \multicolumn{2}{c}{ Kontrol } \\
\cline { 2 - 5 } Hisap & $\mathbf{f}$ & $\%$ & $\mathbf{f}$ & $\%$ \\
Bayi & & & & \\
\hline Baik & 13 & 72,2 & 11 & 61,1 \\
Kurang & 5 & 27,8 & 7 & 38,9 \\
\hline Total & $\mathbf{1 8}$ & $\mathbf{1 0 0}$ & $\mathbf{1 8}$ & $\mathbf{1 0 0}$ \\
\hline
\end{tabular}

Tabel 4 menunjukkan bahwa untuk kelompok intervensi sebagian besar responden memiliki bayi dengan daya hisap baik yaitu sebanyak 13 orang $(72,2 \%)$, sedangkan untuk kelompok kontrol sebagian besar juga responden memiliki bayi dengan daya hisap baik yaitu sebanyak 11 orang $(61,1 \%)$.

Tabel 5. Pengaruh Mobilisasi Ibu Post Partum Terhadap Pengeluaran Kolostrum

\begin{tabular}{lccccc}
\hline \multirow{2}{*}{$\begin{array}{l}\text { Pengeluaran } \\
\text { Kolostrum }\end{array}$} & \multicolumn{4}{c}{ Kelompok } & $\boldsymbol{p}$ \\
\cline { 2 - 5 } & \multicolumn{2}{c}{ Intervensi } & \multicolumn{2}{c}{ Kontrol } & \\
\cline { 2 - 5 } & $\mathbf{f}$ & $\%$ & $\mathbf{f}$ & $\%$ & \\
\hline Early & 13 & 72,2 & 9 & 50,0 & 0,3 \\
Late & 5 & 27,8 & 9 & 50,0 & 05 \\
\hline Total & $\mathbf{1 8}$ & $\mathbf{1 0 0}$ & $\mathbf{1 8}$ & $\mathbf{1 0 0}$ & \\
\hline
\end{tabular}

Tabel 5 menunjukkan bahwa terdapat perbedaan pengeluaran kolostrum antara kelompok intervensi dan kelompok kontrol dimana pada kelompok intervensi pengeluaran kolostrum lebih besar pada pengeluaran kolostrum early (kolostrum yang cepat keluar) dibandingkan pengeluaran kolostrum late (kolostrum yang lambat keluar), sedangkan kelompok kontrol, responden dengan pengeluaran kolostrum early berjumlah sama dengan pengeluaran kolostrum late. Namun dari uji statistik berdasarkan nilai $p>0,05$ yang berarti tidak terdapat pengaruh bermakna antara mobilisasi ibu post partum terhadap pengeluaran kolostrum.

Tabel 6. Pengaruh Faktor Confounding Terhadap Pengeluaran Kolostrum

\begin{tabular}{|c|c|c|c|c|c|c|c|c|c|c|}
\hline Contounainng & & & & & Kelon & & & & & \\
\hline & & & nter & & & & & KoI & & \\
\hline & & गenge & Iara & रoाos & & & enge & ara & KoाOS & \\
\hline & & & & & $\mathbf{p}$ & & & & & $p$ \\
\hline & $t$ & $\%$ & $T$ & $\%$ & & $t$ & $\%$ & $f$ & $\%$ & \\
\hline TIVI & & & & & & & & & & \\
\hline Kurang & 1 & 50 & 1 & 50 & & 2 & 66 & 1 & 33,3 & \\
\hline Normal & 10 & 0 & 6 & 0 & & 9 & 7 & 6 & 40,0 & \\
\hline & & 62 & & 37 & 1000 & & 60 & & & 1,0 \\
\hline & & 5 & & 5 & 1,000 & & 0 & & & 00 \\
\hline Stres & & & & & & & & & & \\
\hline Normal & 3 & 60 & 2 & 40 & & 2 & 50 & 2 & 50,0 & \\
\hline Ringan & 8 & 0 & 5 & 0 & 1000 & 9 & 0 & 5 & 35,7 & 1,0 \\
\hline & & 61 & & 38 & & & 64 & & & 00 \\
\hline & & 5 & & 5 & & & 3 & & & \\
\hline Daya hisap & & & & & & & & & & \\
\hline bayi & & & & & & & & & & \\
\hline Baik & 10 & 76 & 3 & 23 & & 9 & 81 & 2 & 18,2 & \\
\hline Kurang & 1 & 9 & 4 & 1 & 0047 & 2 & 8 & 5 & 71,4 & 0,0 \\
\hline & & 20 & & 80 & 0,047 & & 28 & & & 49 \\
\hline & & 0 & & 0 & & & 6 & & & \\
\hline
\end{tabular}

Pada Tabel 6 menunjukkan bahwa pada status IMT dan tingkat stres responden terlihat nilai $p$ $>0,05$ pada kelompok intervensi dan kontrol yang berarti tidak ada pengaruh bermakna antara tingkat stres ibu terhadap pengeluaran kolostrum, sedangkan daya hisap bayi terlihat nilai $p<0,05$ pada kelompok intervensi dan kontrol yang berarti terdapat pengaruh bermakna antara daya hisap bayi dengan pengeluaran kolostrum.

\section{PEMBAHASAN}

Hasil penelitian mendapatkan bahwa selain mobilisasi ibu, juga terdapat faktor lain yang dapat mempengaruhi pengeluaran kolostrum antara lain status IMT, tingkat stres dan kemampuan daya hisap bayi. 
Mobilisasi akan melibatkan aktifitas fisik yang mempengaruhi kebutuhan otot terhadap peningkatan kebutuhan oksigen yang memerlukan aliran darah yang kuat untuk menjadikan otot rileks sehingga akan melancarkan peredaran dalam tubuh yang akan melibatkan sistem neuron untuk memberikan sinyal syaraf di otak dan melalui perantara yang akan menghubungkan ke hipotalamus yang selanjutnya kehipofisis posterior untuk melepaskan oksitosin dan diangkut oleh darah kepayudara untuk merangsang sel mioepitel membentuk duktus dialveoli sehingga keluarlah kolostrum. ${ }^{9.10}$

ASI dihasilkan melalui proses pembentukan (genesis) yang disebut laktogenesis yang terdiri dari tiga fase. Pada proses laktogenesis II dikendalikan oleh sistem endokrin yang terjadi pada saat kehamilan dan hari-hari pertama persalinan, volume kolostrum dan ASI akan semakin meningkat sekitar 30-40 jam setelah melahirkan, sehingga jika hari-hari pertama atau $<30$ jam bayi sudah lancar menyusu pada ibunya, maka pengeluaran ASI ibu termasuk cepat karena meskipun ASI sudah diproduksi saat pertengahan kehamilan, hormon progesteron yang dihasilkan saat hamil akan menghambat pengeluaran kolostrum dari payudara, oleh karena itu dibutuhkan sistem metabolisme tubuh ibu untuk dapat berfungsi dengan baik saat hari awal persalinan ini, agar bayi dapat segera menyusu dengan baik dan mendapatkan kolostrum sebagai nutrisi bayi yang mengandung immunoglobulin A $(\lg \mathrm{A})$ yang dapat membantu melapisi usus bayi yang masih rentan dan mencegah kuman yang dapat masuk kedalam tubuh bayi. ${ }^{11,12}$

Sesuai pengamatan pada hari pertama intervensi dilakukan, responden pada umumnya masih takut melakukan gerakan dengan alasan masih lelah dengan persalinan yang baru dilalui dan takut mengalami perdarahan, sehingga untuk menyusui bayinya pun masih enggan dilakukan dan ibu lebih memilih untuk berbaring saja. Namun setelah melewati beberapa jam masa nifas selanjutnya dan ibu sudah mendapatkan penjelasan tentang pentingnya mobilisasi, ibu menjadi memahami dan mau mengikuti anjuran bidan sehingga ibu menjadi lebih santai dan rileks dalam menjalani proses masa nifas ini, juga ibu semakin mudah dan termotivasi untuk merawat diri dan bayinya sendiri dengan lebih banyak bersama bayinya dan menyusui bayinya dan akhirnya bayi menjadi semakin sering menyusu pada ibunya.

Hal inilah yang menyebabkan meskipun ibu tidak melakukan mobilisasi, namun ibu mampu dan sering menyusui bayinya, maka rangsangan hisapan bayi ini akan memicu pengeluaran kolostrum cepat terjadi. Penelitian kali ini tidak senada dengan penelitian yang diperoleh Gregory yang mengemukakan bahwa latihan gerakan tubuh pada ibu post partum dapat mempengaruhi produksi dan pengeluaran $\mathrm{ASI}^{13}$ dimana perbedaan dengan penelitian ini yaitu latihan fisik tubuh ibu dilakukan dan diobservasi selama 7 hari dengan jumlah sampel yang lebih besar dan kondisi geografis yang berbeda dengan kondisi penelitian ini, sedangkan penelitian ini hanya dilakukan selama 3 hari dengan alasan responden hanya diobservasi ketika berada di Rumah Sakit saja ketika mengalami perawatan masa nifas normal selama tiga hari.

Wojtyla $^{14}$ juga menyatakan bahwa perlunya latihan mobilisasi tubuh justru harus dimulai sejak kehamilan hingga awal persalinan karena akan memudahkan adaptasi tubuh ibu dengan perubahanperubahan yang terjadi, termasuk menyusui. Masih banyak faktor yang dapat mempengaruhi terjadinya pengeluaran kolostrum, namun pada penelitian kali ini tidak semua faktor dapat diobservasi dengan adanya keterbatasan dari penelitian ini, sehingga apabila penelitian ini disertai dengan melihat semua faktor internal dan eksternal yang berkaitan dengan hal ini maka besar kemungkinan mobilisasi terlihat jelas dapat mempengaruhi terjadinya pengeluaran kolostrum ibu nifas, sehingga bukan hanya karena adanya mobilisasi saja, pengeluaran kolostrum dapat terjadi namun karena adanya faktor lain yang mendukung proses tersebut. Penelitian Velpuri menemukan bahwa menyusui memerlukan sikap dan kepercayaan diri penuh dari si ibu sendiri. ${ }^{15}$ Surtees juga mengemukakan bahwa keberhasilan menyusui memerlukan tekhnik dan dukungan yang positif. ${ }^{16}$

Berdasarkan status IMT ibu, rata-rata pengeluaran kolostrum tidak terdapat perbedaan pada kedua kelompok dimana pada kelompok intervensi dan kontrol lebih banyak terjadi pengeluaran kolostrum early dibandingkan late dengan nilai $>0,05$ yang berarti tidak ada pengaruh yang bermakna. Apabila penelitian 
ini lebih dikhususkan lagi kepada pengukuran status gizi ibu melalui asupan pola makan ibu maka kemungkinan bisa saja faktor status gizi ibu akan terlihat jelas mempengaruhi pengeluaran kolostrum ibu, sebagaimana diketahui bahwa pada masa menyusui kebutuhan zat gizi semakin meningkat dan apabila konsumsi makanan sehari-hari kurang beraneka ragam maka akan timbul ketidakseimbangan antara masukan dan kebutuhan zat gizi yang diperlukan untuk proses produksi, pengeluaran ASI dan proses menyusui selanjutnya. ${ }^{17}$

Pada penelitian ini, kelompok intervensi maupun kelompok kontrol berdasarkan masingmasing tingkat stres ibu, sebagian besar responden dengan pengeluaran kolostrum early, adanya rangsangan hisap bayi akan mengaktifkan kontraksi myoepitel payudara ibu untuk keluarnya ASI. Kondisi ini memberikan gambaran bahwa walaupun secara substansi stres ibu mempengaruhi proses pengeluaran ASI, namun bukan menjadikan satusatunya faktor yang mempengaruhi terjadinya proses tersebut.

Pada proses kelahiran bayi, sering dijumpa ketidakmampuan daya hisap bayi untuk menyusui dengan efektif padahal sudah banyak teori yang ada bahwa isapan bayi yang efektif akan memaksimalkan rangsangan ke otak yang akan memerintahkan untuk memproduksi hormon prolaktin dan oksitosin sehingga produksi dan pengeluaran ASI akan terjadi dan menjadikan proses menyusui berlangsung dengan baik yang akan memberikan dampak positif baik bagi bayi maupun ibu. Beberapa faktor yang mempengaruhi proses menghisap ini antara lain perlekatan yang kurang sempurna karena posisi menyusui yang salah, frekuensi menyusui yang kurang, berat badan bayi lahir ataupun struktur mulut dan rahang bayi yang kurang baik. ${ }^{18}$

Parker $^{19}$ juga mengemukakan bahwa jika bayi sering menghisap puting susu ibunya, maka ASI akan semakin banyak keluar hingga hari-hari selanjutnya. Rangsangan yang ditimbulkan bayi saat menyusu diantar sampai bagian belakang kelenjar hipofise yang akan melepaskan hormon oksitosin masuk ke dalam darah.

\section{KESIMPULAN}

Persentase pengeluaran kolostrum early kelompok intervensi lebih besar dibandingkan kelompok kontrol, namun secara statistik tidak terdapat pengaruh bermakna mobilisasi ibu post partum terhadap pengeluaran kolostrum pada kedua kelompok tersebut. Tidak terdapat pengaruh yang bermakna antara status IMT dan tingkat stres ibu pada kelompok intervensi dan kontrol. Terdapat pengaruh yang bermakna antara daya hisap bayi terhadap pengeluaran kolostrum pada kelompok intervensi dan kontrol.

\section{UCAPAN TERIMA KASIH}

Penulis mengucapkan terima kasih kepada Poltekkes Kemenkes Kendari atas kesempatan yang diberikan untuk melanjutkan pendidikan.Kepada RSU Bahteramas Sulawesi Tenggara sebagai tempat penelitian atas fasilitas yang telah diberikan. Kepada DR. dr. Joserizal Serudji, SpOG(K) dan Sunesni, S.Si.T, M.Biomed sebagai pembimbing atas masukan dan bimbingan dalam menyelesaikan tesis ini.

\section{DAFTAR PUSTAKA}

1. BAPPENAS. Laporan pencapaian tujuan pembangunan millennium di Indonesia Jakarta; 2012.

2. Amanda J. Breast milk composition after exercise of different intensities: a review. Nigeria Journal of Clinical Practice. 2012 Feb (diunduh 12 Oktober 2013). Tersedia dari: URL: HYPERLINK http://wwwpediatrics.apppublications.org.htm

3. Abba AM. A qualitatif study of the promotion of exlusife breastfeeding by health professionals in niamy. Internastional Breastfeeding Journal. 2010; 5:1-7.

4. Bobak M, Lawdermilk, Jensen MD. Buku ajar keperawatan maternitas. Edisi ke-4. Maria AW, editor bahasa Indonesia. Jakarta: EGC; 2005.

5. Larson M, Dawnine E. Effect of postpartum exercise on mothers and their offspring: a review of the literature. Feb-Mei 2010;10(10):841-53.

6. Dewey KG. A randomized study of the effects of aerobic exercise by lactating women on breast-milk 
volume and composition. Notherland England Journal Medical.1994;7:449-53

7. Cunningham F. Obstetri Williams. Edisi ke-21. Profitasari, editor bahasa Indonesia. Jakarta: EGC;2013.

8. Sastroasmoro S. Dasar-dasar metodologi penelitian klinis. Edisi ke-4. Jakarta: CV Sagung Seto;2011.

9. Guyton Hall. Buku Ajar Fisiologi Kedokteran. Edisi ke-12. Djauhari $M$, editor bahasa Indonesia. Jakarta:EGC;2008.

10. Kendall, Tao. Sinopsis organ system endokrinologi. Tangerang: Karisma Publishing Group;2013.

11. Ganong WF. Buku ajar fisiologi kedokteran. Djauhari M, editor bahasa Indonesia. Jakarta:EGC; 2008.

12. Cameron J. Fisika tubuh manusia. Edisi 2. Jakarta: EGC; 2006.

13. Gregory RL. Effect of exercise on milk immunoglobulin A. Med Sci Sports Exerc.Dec 2009;12:1596-601.
14. Wojtyła A. Epidemiological studies in Poland on effect of physical activity of pregnant women: a review. Am Journal Breastfeeding. Jan 2012; 19(5):315-9.

15. Velpuri J. Breastfeeding of knowledge and attitudes, beleifs, and intentions regarding breastfeeding of workplace among students and professionals in health-reletad fileds. Jan 2004;10(5):159-68.

16. Surtees A. Maternity focus: techniques to support breastfeeding. British Journal of Healthcare Assistens. Feb 2011; 05(3):134-6.

17. Sherwood, Laralee. Fisiologi manusia. Edisi ke-6. Jakarta: EGC; 2012.

18. Syaifuddin. Fisiologi tubuh manusia. Edisi ke-2. Jakarta: Salemba Medika;2013.

19. Parker, Sullivan. Effect of early breast milk expression on milk volume and timing of lactogenesis stage II among mothers of very low birth weight infants: a pilot study; 2012 Mar (diunduh 20 September 2013). Tersedia dari: URL: HYPERLINK http://www.nature.com/jp.htm 